\title{
Ketamine for the treatment of depression in patients receiving hospice care: a retrospective medical record review of thirty-one
}

cases.

\author{
Alana Iglewicz \\ University of California \\ Katherine Morrison \\ University of Colorado \\ Richard A. Nelesen \\ University of California
}

Follow this and additional works at: https://jdc.jefferson.edu/petfp

Tingting Zhan

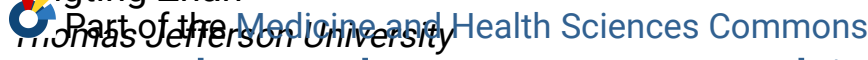

Let us know how access to this document benefits you

Temple University

Recommended Citation

Iglewicz, Alana; Morrison, Katherine; Nelesen, Richard A.; Zhan, Tingting; Iglewicz, Boris;

See next page for additional authors
Fairman, Nathan; Hirst, Jeremy M.; and Irwin, Scott A., "Ketamine for the treatment of

depression in patients receiving hospice care: a retrospective medical record review of thirty-

one cases." (2015). Department of Pharmacology and Experimental Therapeutics Faculty

Papers. Paper 69.

https://jdc.jefferson.edu/petfp/69

This Article is brought to you for free and open access by the Jefferson Digital Commons. The Jefferson Digital Commons is a service of Thomas Jefferson University's Center for Teaching and Learning (CTL). The Commons is a showcase for Jefferson books and journals, peer-reviewed scholarly publications, unique historical collections from the University archives, and teaching tools. The Jefferson Digital Commons allows researchers and interested readers anywhere in the world to learn about and keep up to date with Jefferson scholarship. This article has been accepted for inclusion in Department of Pharmacology and Experimental Therapeutics Faculty Papers by an authorized administrator of the Jefferson Digital Commons. For more information, please contact:

JeffersonDigitalCommons@jefferson.edu. 


\section{Authors}

Alana Iglewicz, Katherine Morrison, Richard A. Nelesen, Tingting Zhan, Boris Iglewicz, Nathan Fairman, Jeremy M. Hirst, and Scott A. Irwin 


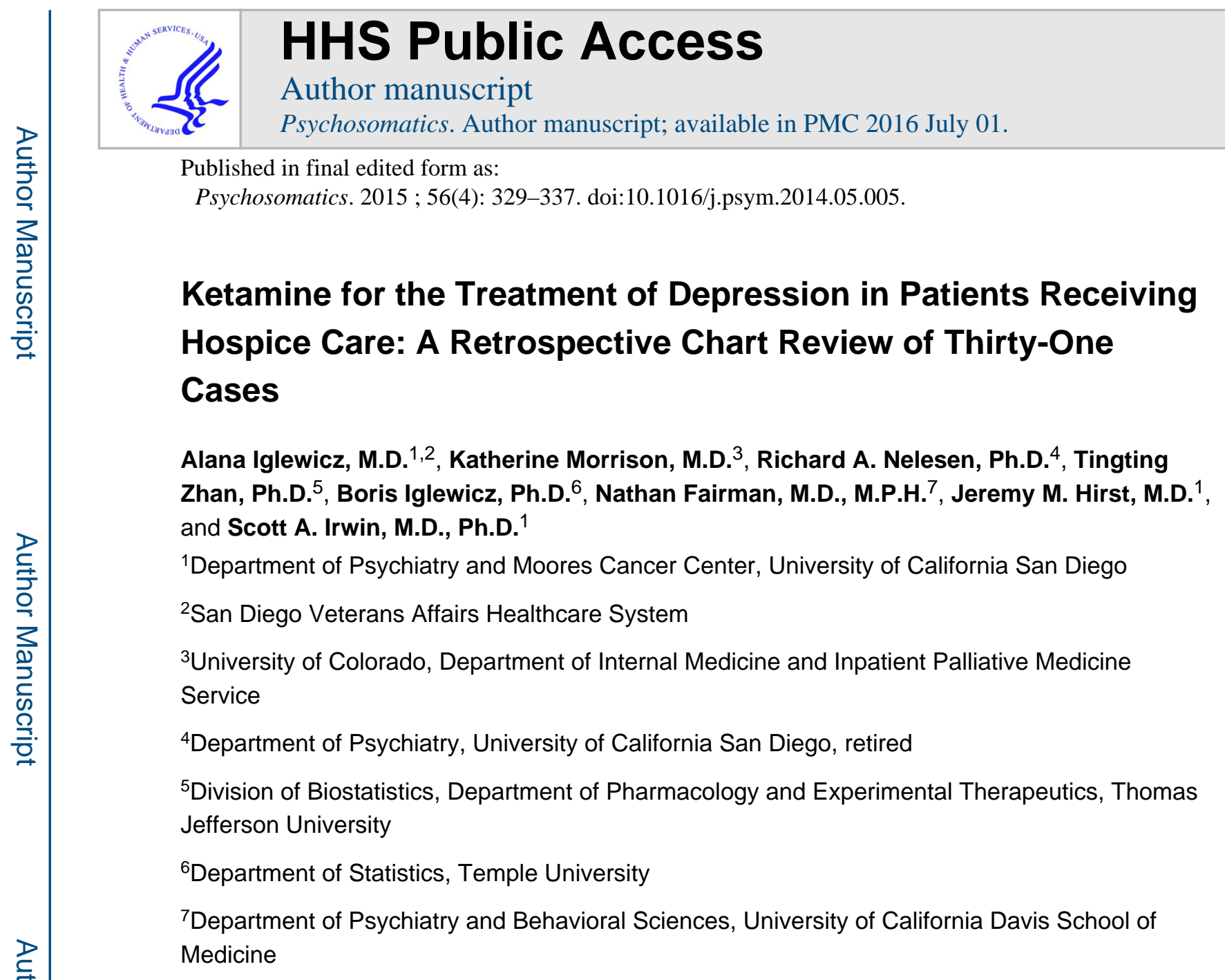

\section{Abstract}

Background-Depression is prevalent in patients receiving hospice care. Standard antidepressant medications do not work rapidly enough in this setting. Evidence suggests that ketamine rapidly treats treatment refractory depression in the general population. Ketamine's role for treating depression in the hospice population warrants further study.

Methods-A retrospective chart review of 31 inpatients receiving hospice care who received ketamine for depression on a clinical basis was conducted. The primary outcome measure was the Clinical Global Impression Scale, which was used retrospectively to rate subjects' therapeutic

(C) 2014 Academy of Psychosomatic Medicine. Published by Elsevier Inc. All rights reserved

Address correspondence and reprint requests to: Scott A. Irwin, MD, PhD, Director, Psychiatry \& Psychosocial Services; Patient \& Family Support Services, UC San Diego Moores Cancer Center, Director, Palliative Care Psychiatry, UC San Diego Health System, Associate Clinical Professor, Psychiatry, UC San Diego School of Medicine, 3855 Health Sciences Dr. \#0658, La Jolla, CA 92093-0658, (858) 822-0076, sirwin@ucsd.edu.

Disclosure

This work was supported, in part, by the National Palliative Care Research Center, Award Number K23MH091176 from the National Institute of Mental Health, and by donations from the generous benefactors of the education and research programs at San Diego Hospice and The Institute for Palliative Medicine. The authors report no proprietary or commercial interest in any product mentioned or concept discussed in this article.

Publisher's Disclaimer: This is a PDF file of an unedited manuscript that has been accepted for publication. As a service to our customers we are providing this early version of the manuscript. The manuscript will undergo copyediting, typesetting, and review of the resulting proof before it is published in its final citable form. Please note that during the production process errors may be discovered which could affect the content, and all legal disclaimers that apply to the journal pertain. 
improvement, global improvement, and side effects from ketamine over 21 days. Additionally, time to onset of therapeutic effect was also analyzed.

Results-Using the CGI, ketamine was found to be significantly therapeutically effective through the first week after ketamine dosing ( $<<0.05$ ), with 93\% of subjects showing positive results for days $0-3$ and $80 \%$ for days $4-7$ post ketamine dosing. Subjects experienced global improvement during all four time periods post ketamine dosing (all p-values $<0.05$ ). Significantly more subjects had either no side effects or side effects that did not significantly impair functioning at each of the four assessed time periods post ketamine dosing (all p-values < 0.05). Additionally, significantly more subjects experienced their first therapeutic response during days $0-1$ post ketamine dosing $(\mathrm{p}<0.001)$ than during any other time period.

Conclusions-These data suggest that ketamine may be a safe, effective, and rapid treatment for clinical depression in patients receiving hospice care. Blinded, randomized, and controlled trials are required to substantiate these findings and support further clinical use of this medication in hospice settings.

\section{Keywords}

Ketamine; Depression; Antidepressant; Hospice; Palliative Care; Psychiatry; NMDA; glutamate

\section{Introduction}

Depression is one of the leading causes of disability worldwide (1) and is associated with increased morbidity and mortality (2-5). Standard antidepressants typically take four to six weeks to reach maximal effectiveness, and monotherapy with standard antidepressants is only effective approximately $35 \%$ of the time, often necessitating multiple trials of antidepressants $(6,7)$. Thus, there is mounting interest in possible treatments for depression that work more rapidly. This is especially true for populations with short prognoses, such as those receiving hospice care.

Psychostimulants, such as methylphenidate, are often used in hospice settings to rapidly treat depression, with some evidence to support this practice. (8-17) However, methylphenidate does not work for every patient, and its use can be limited by the development of anxiety, insomnia, agitation, and at times, mania. $(18,19)$

Ketamine, an N-methyl-D-aspartate (NMDA) receptor antagonist, is another possible treatment. A growing body of literature, ranging from case reports to randomized controlled trials, supports the use of sub-anesthetic doses of intravenous (IV) infusions of ketamine at $0.5 \mathrm{mg} / \mathrm{kg}$ over 4 hours to treat depressive symptoms in individuals with treatment resistant depression (20-37). Ketamine's antidepressant properties are thought to be associated with its effects on the NMDA-receptor channel, glutamate transmission, mTOR-dependent synapse formation, cholinergic transmission, noradrenergic and serotonergic reuptake inhibition, as well as its interactions with other calcium and sodium channels (38-40).

Ketamine's antidepressant properties are of great interest for patients receiving hospice care. Up to $42 \%$ of hospice patients have symptoms of depression. (41-43) Untreated depression in patients receiving hospice care is associated with significant morbidity and mortality. (44, 
45) Since the average time patients received hospice care in the US in 2012 was around 10 weeks, (with the median being less than 3 weeks)(46) and because standard pharmacologic treatments for depression take several weeks to reach maximal effect, many hospice patients will not live long enough to realize the benefits of standard treatments for depression. For these reasons, there is a growing interest in pharmacological treatments for depression with a rapid therapeutic effect such as ketamine.

Notably, a robust literature supports the safe and tolerable use of sub-anesthetic doses of ketamine for the treatment of pain in hospice patients (47-56). Furthermore, in both a small case series and an open label-trial, oral ketamine was found to be a fairly rapid, safe, and tolerable treatment for depression in patients receiving hospice care (57-59). In addition, these studies described a decrease in symptoms of anxiety with no insomnia or psychomimetic effects noted. In fact, most somatic symptoms improved.

Data from a retrospective chart review of the use of ketamine to clinically treat depression in patients receiving hospice care are presented in this paper. The objectives of this study are to provide preliminary data about the efficacy, tolerability, time to efficacy, duration of response, and side effects of ketamine for the treatment of depression in patients receiving hospice care. These results will inform future randomized controlled trials that are needed to definitively answer such questions.

\section{Methods}

The study was approved by the San Diego Hospice and The Institute for Palliative Medicine Institutional Review Board. Pharmacy data from 2005-2011 were used to identify patients who had received ketamine while being treated at an inpatient hospice care center. Thirtythree patients were prescribed ketamine for depression and 31 of these received ketamine for the first time during their inpatient admission. A retrospective review of these 31 charts was conducted.

Inter-rater reliability was established using three charts (10\%). Each of these three charts was reviewed by all three raters, two of whom were board certified psychiatrists and one of whom was a board certified palliative care specialist. For the remaining 26 charts, each chart was reviewed by one of these three raters.

Each chart was evaluated for 1) demographic variables, 2) psychiatric diagnoses and treatments, 3) ketamine dosage, route, and frequency of dose, 4) time to first response of depressive symptoms, 5) time to maximal response of depressive symptoms, 6) duration of response to ketamine, and 7) ketamine related side effects. Data was collected for predetermined time periods consisting of days $0-1,2-3,4-7$, and $8-21$ post-ketamine dosing. These time periods were chosen to capture possible rapid effects of ketamine, protracted effects, and longer-term effects based on the literature and our experience with an open-label trial. (58) In addition, we wanted to be vigilant about adverse events. Lastly, as this was a retrospective review, depression may not have been evaluated or commented on each day by the primary palliative care team. 
The Clinical Global Impression (CGI) scale was completed retrospectively based on palliative care team charting to evaluate subjects' baseline clinical status pre-ketamine dosing and changes in the subjects' clinical outcomes/side effects post-ketamine dosing. (60) CGI ratings were determined based on the notes regarding depression written by psychiatric consultants, primary physicians, nurses, and social workers each day of the inpatient admission prior to ketamine dosing and each day during the four assessment time periods, as available. Depression was not necessarily commented on in the charts each day for each patient.

Global improvement ratings on the CGI reflect improvement, whether or not the improvement is due entirely to the drug treatment and range from "very much improved" (score of 1) to "very much worse" (score of 7) with (1) very much improved; (2) much improved; (3) minimally improved; (4) no change; (5) minimally worse; (6) much worse; and (7) very much worse. Scores of 1-3 were categorized as positive outcomes and scores of 5-7 were categorized as negative outcomes.

The Efficacy Index of the CGI has two components, the therapeutic effect and side effects, and is based specifically on the drug effect (i.e. response to ketamine). The therapeutic effect reflects how much the condition has improved related to the study medication and ranges from "unchanged or worse" (score of 1) to "marked" improvement (score of 4) with (1) unchanged to worse; (2) minimal; (3) moderate; and (4) marked improvement. Scores of 1 were categorized as negative outcomes and scores of 2-4 were categorized as positive outcomes.

Side effect ratings on the CGI's Efficacy of Index range from "none" (score of 1) to "outweighs therapeutic effect" (score of 4) with (1) none; (2) do not significantly interfere with patient functioning; (3) significantly interferes with patient functioning; and (4) outweighs therapeutic effect. Scores of 1-2 were categorized as positive outcomes and scores of 3-4 were categorized as negative outcomes.

Simple, formal, two-sided significance tests, based directly on binomial distribution and providing exact $\mathrm{p}$ - values, were performed for each CGI measure categorized into negative outcome versus positive outcome classifications and assumed as the null hypothesis that a subject had an equal chance of being classified in each.

For patients who only received one dose of ketamine, exact $\mathrm{p}$ - values, using a binomial distribution, were also obtained for the analyses of 1) time to first response, 2) time to maximal response, 3) time to fading of response, and 3) number of side effects, with the null hypothesis being that subjects had an equal chance of being in each cell (with the cells being the time periods of days $0-1,2-3,4-7$, and 8-21 post-ketamine dosing for the analyses of "time to ..."; and 0 side effects, 1 side effect, $2-3$ side effects, and 4 or more side effects for "number of side effects"). 


\section{Results}

Sample

The sample was comprised of 11 male and 20 female subjects. The subjects ranged in age from 44 to 89 years, with a mean age of 68 years and a median age of 66 years (Table 1).

The observed numbers of subjects for the CGI analyses were: 29 for days $0-1 ; 28$ for days $2-3$; 20 for days $4-7$; and 10 for days $8-21$ post ketamine dosing respectively, except that only 28 patients were noted to be observed for side effects during the days $0-1$ post ketamine dosing period.

\section{Ketamine Dosing}

Twenty two patients received a single dose of ketamine at $0.5 \mathrm{mg} / \mathrm{kg}$, and five received a single $0.5 \mathrm{mg} / \mathrm{kg}$ dose followed by a single repeat dose of $0.5 \mathrm{mg} / \mathrm{kg}$. Four received three times a day dosing each day they were studied, each dose again at $0.5 \mathrm{mg} / \mathrm{kg}$. Twenty nine patients received an oral formulation of ketamine, one received a single oral dose followed by a single subcutaneous dose, and one received a single subcutaneous dose (Table 2).

\section{Inter-rater Reliability}

For measuring Global Improvement, the three raters had substantial agreement with Fleiss's kappa $=0.65(\mathrm{p}<0.001,95 \% \mathrm{CI}(0.45,0.85))$ and Kendall's coefficient of concordance of $0.99(\mathrm{p}=0.002,95 \% \mathrm{CI}(0.91,1))$.

For the Efficacy Index, the three raters had almost perfect agreement with Fleiss's kappa $=1$ $(\mathrm{p}<0.001,95 \%$ CI $(0.80,1))$ and Kendall's coefficient of concordance of $1(\mathrm{p}<0.001,95 \%$ CI $(0.93,1))$.

\section{Response to Ketamine}

Therapeutic Effect Scale of the CGI-For the therapeutic effect rating on the CGI, positive therapeutic outcomes were more common than negative therapeutic outcomes at time periods days $0-1(\mathrm{p}<0.001)$, days $2-3(\mathrm{p}<0.001)$, and days $4-7(\mathrm{p}<0.05)$ post dosing (Table 3a). Overall, ketamine was therapeutically effective through the first week post dosing. Figure 1A shows the therapeutic effect scale of the CGI outcomes, in which $93 \%$ of the patients showed positive results during days $0-3,80 \%$ during days $4-7$, and $60 \%$ during days 8-21 post dosing (Figure 1A).

Global Improvement Scale of the CGI-For the global improvement measure of the CGI, which assesses overall clinical improvement whether or not it was thought to relate to ketamine administration, positive therapeutic outcomes were more common than were negative therapeutic outcomes at all assessed time periods post ketamine dosing ( $\mathrm{p}<0.05$ at days $0-1,2-3,4-7$, and $8-21$ post ketamine dosing) (Table $3 b$ ). Figure $1 \mathrm{~B}$ shows the outcomes for the CGI global improvement scale, in which 52\%, 46\%, 55\%, and $80 \%$ of the patients had positive global improvement over the respective four post dosing assessment periods and no patients were classified as "much worse" or "very much worse" at any time point. 
Time to First Response-Of the 22 subjects who received a single dose of ketamine, we were able to determine the time to first response for 14 subjects. Ten had their first response either on the day of ketamine dosing or day 1 post ketamine dosing and 4 had their first response on days 2-3 post ketamine dosing. None had their first response on days 4-21 post ketamine dosing. Significantly more subjects showed their first response on days $0-1$ post ketamine dosing $(\mathrm{p}<0.05)$ than at any other time point (Table 4$)$.

Time to Maximum Response-Of the 22 subjects who received a single dose of ketamine, we were able to determine the time to maximum response for 11 subjects. Maximum response occurred for 4 subjects on days 0-1, 4 subjects on days 2-3, 2 subjects on days $4-7$, and 1 subject on days $8-21$ post ketamine dosing. There were no statistically significant differences indicating that maximal response occurred during one time period more commonly than any other (Table 4).

Fading of Response-Of the 22 subjects who received a single dose of ketamine, we were able to determine the time that the response started to fade for 6 subjects. The fading of response started in 5 subjects on days 2-3 and 1 subject on days 4-7 post ketamine dosing and was more common on days $2-3$ post ketamine dosing $(\mathrm{p}<.05)$ than at any other time point (Table 4).

\section{Side Effects}

Side Effect Scale of the CGI-For the side effect measure of the CGI, the vast majority of subjects did not experience clinically significant side effects. More subjects had positive therapeutic outcomes (either no side effects or side effects that had no interference with functioning) than negative therapeutic outcomes (either significantly interfered with functioning or outweighed therapeutic effects) at all assessed time points post ketamine dosing ( $\mathrm{p}<0.001$ at days $0-1$ and $8-21$ and $\mathrm{p}<0.05$ at days $2-3$ and $4-7$ post ketamine dosing) (Table 3c).

Figure 1C summarizes the data from the side effect scale of the CGI. Ninety-six percent, $71 \%, 85 \%$, and $100 \%$ had either no side effects or side effects which did not interfere with functioning over the respective four post dosing assessment periods.

Side Effect Descriptions-Of those who received a single dose of ketamine, 9 experienced possible ketamine related side effects. All of the reported side effects were categorized as psychiatric: 7 subjects $(45.5 \%)$ experienced disorientation, $4(18.2 \%)$ had hallucinations, 4 (18.2\%) had sedation, 1 (4.5\%) had insomnia, $1(4.5 \%)$ had delusions, and $1(4.5 \%)$ had anxiety. Three (13.6\%) had only 1 side effect, and $6(27.3 \%)$ had 2-3 psychiatric side effects. Thirteen subjects $(59.1 \%)$ had no side effects. Significantly more subjects had no side effects than any number of side effects $(\mathrm{p}<0.05)$ (Table 4$)$.

\section{Discussion}

This retrospective chart review represents a first step in providing preliminary data about the efficacy, tolerability, time to efficacy, duration of response, and side effects of ketamine for the treatment of depression in patients receiving hospice care. These results suggest the 
utility of moving forward with randomized controlled trials. The overall findings support the potential for rapid efficacy and acceptable tolerability of ketamine in treating depression in this population. Ketamine, which was dosed orally the majority of the time, demonstrated rapid antidepressant properties, with efficacy typically occurring within 1 day of ketamine dosing.

The sustained effects of ketamine dosing were mixed. The vast majority of subjects in this study only received a single dose of ketamine and over half of those who experienced clinical benefit from ketamine started to show a fading of their response between days 2 and 7 post ketamine dosing, which is consistent with findings in the literature. (20-37) However, a recent open label trial indicates that daily dosing is associated with minimal side effects and a more sustained effect (58). Further study is required to determine when and how frequently ketamine dosing should be repeated, and by what route.

Ketamine was well tolerated by the subjects in this study. Most subjects did not appear to experience any side effects from ketamine. When side effects were present, they were all categorized as psychiatric rather than somatic. This fits the findings from the open label trial (58), which suggested that side effects were rare and somatic symptoms often lessened after ketamine dosing. Ratings indicate that when side effects were present, they rarely interfered with functioning, suggesting that they were mild and likely tolerable. However, caution should be used when considering these results given the high propensity for delirium in this population. (61)

The vast majority of subjects received ketamine by the oral route. The effectiveness and safety of ketamine use might theoretically improve with oral administration due to first pass metabolism to norketamine (62). Importantly, oral dosing is much more practical and less invasive than is intravenous dosing in many patient populations, especially hospice populations. It can be administered in ambulatory care settings and does not require advanced hospital resources or the presence of anesthesia services. Furthermore, complications of intravenous catheter placement are numerous, especially in medically ill populations and include placement difficulty, diminishing site availability, need for site rotation every few days, infection, malfunction, thrombosis, and extravasation--all of which decrease comfort and increase the cost of care (63-65). The ability to effectively dose ketamine orally would be beneficial for all patients, especially those with serious medical illness and those who prefer to receive treatment in settings other than a hospital.

A chart review comes with natural limitations. It is not randomized, controlled, blinded or prospective in nature. Symptoms and diagnoses are not always documented consistently in the medical chart, nor are they documented in a scientifically rigorous way. One must thus take caution in generalizing the results of this study, both within the hospice population as well as to other patient populations. Another limitation of this particular study is the average hospice length of stay of the patients who were included exceeded national averages. Thus, these results may be less generalizable to typical hospice populations. However, these subjects still represent an important medically ill sample of patients who benefited from palliative care provided in a hospice setting and were in need of rapid amelioration of their depressive symptoms. 
Despite these limitations, the results of this exploratory chart review suggest that ketamine, which was most often orally administered, may be safe and effective for the rapid treatment of depression in a clinically diverse group of patients receiving hospice care. Further systematic study is needed to substantiate these results, as well as to determine the ideal dose, formulation, frequency of dosing, and clinical profile of patients who will best respond to and tolerate ketamine for the treatment of their depression.

A great need for a rapid acting antidepressant agent in patients receiving hospice care exists. This is a population that does not have time to wait for standard antidepressants to take effect. The treatment of depression has profound consequences on quality of life for both these patients and their families. This study helps set the stage for randomized controlled trials which can more definitively determine whether ketamine, which is inexpensive and easy to administer by multiple routes, may be an answer for this need.

\section{Acknowledgments}

We are eternally grateful for the support and participation of the wonderful staff, patients, families, and volunteers of San Diego Hospice and The Institute for Palliative Medicine, as well as Derek Koo and JSN TANAS. RIP San Diego Hospice.

\section{References}

1. Brundtland GH. From the World Health Organization. Mental health: new understanding, new hope. JAMA. 2001; 286(19):2391. [PubMed: 11712923]

2. Carney RM, Blumenthal JA, Catellier D, Freedland KE, Berkman LF, Watkins LL, et al. Depression as a risk factor for mortality after acute myocardial infarction. Am J Cardiol. 2003; 92(11):1277-81. [PubMed: 14636903]

3. Barth J, Schumacher M, Herrmann-Lingen C. Depression as a risk factor for mortality in patients with coronary heart disease: a meta-analysis. Psychosom Med. 2004; 66(6):802-13. [PubMed: 15564343]

4. Carney RM, Freedland KE. Depression, mortality, and medical morbidity in patients with coronary heart disease. Biol Psychiatry. 2003; 54(3):241-7. [PubMed: 12893100]

5. Satin JR, Linden W, Phillips MJ. Depression as a predictor of disease progression and mortality in cancer patients: a meta-analysis. Cancer. 2009; 115(22):5349-61. [PubMed: 19753617]

6. Trivedi MH, Rush AJ, Wisniewski SR, Nierenberg AA, Warden D, Ritz L, et al. Evaluation of outcomes with citalopram for depression using measurement-based care in STAR*D: implications for clinical practice. Am J Psychiatry. 2006; 163(1):28-40. [PubMed: 16390886]

7. Thase ME, Friedman ES, Biggs MM, Wisniewski SR, Trivedi MH, Luther JF, et al. Cognitive therapy versus medication in augmentation and switch strategies as second-step treatments: a STAR*D report. Am J Psychiatry. 2007; 164(5):739-52. [PubMed: 17475733]

8. Clinical Pharmacology Online. 2008.

9. Matsuo N, Morita T. Physician-Reported Practice of the Use of Methylphenidate in Japanese Palliative Care Units. J Pain Symptom Manage. 2007; 33(6):655-6. [PubMed: 17531905]

10. Hardy SE. Methylphenidate for the treatment of depressive symptoms, including fatigue and apathy, in medically ill older adults and terminally ill adults. Am J Geriatr Pharmacother. 2009; 7(1):34-59. [PubMed: 19281939]

11. Fernandez F, Adams F, Holmes VF, Levy JK, Neidhart M. Methylphenidate for depressive disorders in cancer patients. An alternative to standard antidepressants. Psychosomatics. 1987; 28(9):455-61. [PubMed: 3432548]

12. Bruera E, Driver L, Barnes EA, Willey J, Shen L, Palmer JL, et al. Patient-controlled methylphenidate for the management of fatigue in patients with advanced cancer: a preliminary report. J Clin Oncol. 2003; 21(23):4439-43. [PubMed: 14645434] 
13. Wallace AE, Kofoed LL, West AN. Double-blind, placebo-controlled trial of methylphenidate in older, depressed, medically ill patients. Am J Psychiatry. 1995; 152(6):929-31. [PubMed: 7755127]

14. Homsi J, Nelson KA, Sarhill N, Rybicki L, LeGrand SB, Davis MP, et al. A phase II study of methylphenidate for depression in advanced cancer. Am J Hosp Palliat Care. 2001; 18(6):403-7. [PubMed: 11712722]

15. Macleod AD. Methylphenidate in terminal depression. J Pain Symptom Manage. 1998; 16(3):1938. [PubMed: 9769622]

16. Fernandez F, Levy JK, Samley HR, Pirozzolo FJ, Lachar D, Crowley J, et al. Effects of methylphenidate in HIV-related depression: a comparative trial with desipramine. Int J Psychiatry Med. 1995; 25(1):53-67. [PubMed: 7649718]

17. Lee H, Kim SW, Kim JM, Shin IS, Yang SJ, Yoon JS. Comparing effects of methylphenidate, sertraline and placebo on neuropsychiatric sequelae in patients with traumatic brain injury. Human psychopharmacology. 2005; 20(2):97-104. [PubMed: 15641125]

18. Angrist B, d'Hollosy M, Sanfilipo M, Satriano J, Diamond G, Simberkoff M, et al. Central nervous system stimulants as symptomatic treatments for AIDS-related neuropsychiatric impairment. J Clin Psychopharmacol. 1992; 12(4):268-72. [PubMed: 1527230]

19. Stahl, SM. Stahl's essential psychopharmacology: Neuroscientific basis and practical applications. 3. Cambridge; New York: Cambridge University Press; 2008.

20. Krystal JH. Ketamine and the potential role for rapid-acting antidepressant medications. Swiss Med Wkly. 2007; 137(15-16):215-6. [PubMed: 17525875]

21. Kudoh A, Takahira Y, Katagai H, Takazawa T. Small-dose ketamine improves the postoperative state of depressed patients. Anesth Analg. 2002; 95(1):114-8. table of contents. [PubMed: 12088953]

22. Zarate CA Jr, Singh JB, Carlson PJ, Brutsche NE, Ameli R, Luckenbaugh DA, et al. A randomized trial of an N-methyl-D-aspartate antagonist in treatment-resistant major depression. Arch Gen Psychiatry. 2006; 63(8):856-64. [PubMed: 16894061]

23. Berman RM, Cappiello A, Anand A, Oren DA, Heninger GR, Charney DS, et al. Antidepressant effects of ketamine in depressed patients. Biol Psychiatry. 2000; 47(4):351-4. [PubMed: 10686270]

24. Correll GE, Futter GE. Two case studies of patients with major depressive disorder given low-dose (subanesthetic) ketamine infusions. Pain Med. 2006; 7(1):92-5. [PubMed: 16533209]

25. Liebrenz M, Borgeat A, Leisinger R, Stohler R. Intravenous ketamine therapy in a patient with a treatment-resistant major depression. Swiss Med Wkly. 2007; 137(15-16):234-6. [PubMed: 17525879]

26. Liebrenz M, Stohler R, Borgeat A. Repeated intravenous ketamine therapy in a patient with treatment-resistant major depression. The world journal of biological psychiatry : the official journal of the World Federation of Societies of Biological Psychiatry. 2007:1-4.

27. aan het Rot M, Collins KA, Murrough JW, Perez AM, Reich DL, Charney DS, et al. Safety and efficacy of repeated-dose intravenous ketamine for treatment-resistant depression. Biol Psychiatry. 2010; 67(2):139-45. [PubMed: 19897179]

28. Phelps LE, Brutsche N, Moral JR, Luckenbaugh DA, Manji HK, Zarate CA Jr. Family history of alcohol dependence and initial antidepressant response to an N-methyl-D-aspartate antagonist. Biol Psychiatry. 2009; 65(2):181-4. [PubMed: 18996507]

29. DiazGranados N, Ibrahim LA, Brutsche NE, Ameli R, Henter ID, Luckenbaugh DA, et al. Rapid resolution of suicidal ideation after a single infusion of an N-methyl-D-aspartate antagonist in patients with treatment-resistant major depressive disorder. J Clin Psychiatry. 2010; 71(12):160511. [PubMed: 20673547]

30. Price RB, Nock MK, Charney DS, Mathew SJ. Effects of intravenous ketamine on explicit and implicit measures of suicidality in treatment-resistant depression. Biol Psychiatry. 2009; 66(5): 522-6. [PubMed: 19545857]

31. Larkin GL, Beautrais AL. A preliminary naturalistic study of low-dose ketamine for depression and suicide ideation in the emergency department. Int J Neuropsychopharmacol. 2011; 14(8): 1127-31. [PubMed: 21557878] 
32. Zarate CA Jr, Brutsche NE, Ibrahim L, Franco-Chaves J, Diazgranados N, Cravchik A, et al. Replication of Ketamine's Antidepressant Efficacy in Bipolar Depression: A Randomized Controlled Add-On Trial. Biol Psychiatry. 2012; 71(11):939-46. [PubMed: 22297150]

33. Ibrahim L, Diazgranados N, Franco-Chaves J, Brutsche N, Henter ID, Kronstein P, et al. Course of improvement in depressive symptoms to a single intravenous infusion of ketamine vs add-on riluzole: results from a 4-week, double-blind, placebo-controlled study. Neuropsychopharmacology. 2012; 37(6):1526-33. [PubMed: 22298121]

34. Cusin C, Hilton GQ, Nierenberg AA, Fava M. Long-term maintenance with intramuscular ketamine for treatment-resistant bipolar II depression. Am J Psychiatry. 2012; 169(8):868-9. [PubMed: 22854933]

35. Zarate CA Jr, Brutsche NE, Ibrahim L, Franco-Chaves J, Diazgranados N, Cravchik A, et al. Replication of ketamine's antidepressant efficacy in bipolar depression: a randomized controlled add-on trial. Biol Psychiatry. 2012; 71(11):939-46. [PubMed: 22297150]

36. Murrough JW, Iosifescu DV, Chang LC, Al Jurdi RK, Green CE, Perez AM, et al. Antidepressant efficacy of ketamine in treatment-resistant major depression: a two-site randomized controlled trial. Am J Psychiatry. 2013; 170(10):1134-42. [PubMed: 23982301]

37. Murrough JW, Perez AM, Pillemer S, Stern J, Parides MK, aan het Rot M, et al. Rapid and longerterm antidepressant effects of repeated ketamine infusions in treatment-resistant major depression. Biol Psychiatry. 2013; 74(4):250-6. [PubMed: 22840761]

38. Maeng S, Zarate CA Jr, Du J, Schloesser RJ, McCammon J, Chen G, et al. Cellular mechanisms underlying the antidepressant effects of ketamine: role of alpha-amino-3-hydroxy-5methylisoxazole-4-propionic acid receptors. Biol Psychiatry. 2008; 63(4):349-52. [PubMed: 17643398]

39. Li N, Lee B, Liu RJ, Banasr M, Dwyer JM, Iwata M, et al. mTOR-dependent synapse formation underlies the rapid antidepressant effects of NMDA antagonists. Science. 2010; 329(5994):95964. [PubMed: 20724638]

40. Murrough JW. Ketamine as a novel antidepressant: from synapse to behavior. Clin Pharmacol Ther. 2012; 91(2):303-9. [PubMed: 22205190]

41. Wilson, KG.; Chochinov, HM.; de Faye, BJ.; Breitbart, W. Diagnosis and Management of Depression in Palliative Care. In: Chochinov, HM.; Breitbart, W., editors. Handbook of psychiatry in palliative medicine. New York: Oxford University Press; 2000. p. 25-50.

42. NIH. National Institutes of Health State-of-the-Science Conference Statement: Symptom Management in Cancer: Pain, Depression, and Fatigue, July 15-17, 2002. J Natl Cancer Inst Monographs. 2004; 2004(32):9-16.

43. Wilson KG, Chochinov HM, Skirko MG, Allard P, Chary S, Gagnon PR, et al. Depression and anxiety disorders in palliative cancer care. J Pain Symptom Manage. 2007; 33(2):118-29. [PubMed: 17280918]

44. McDaniel, JS.; Brown, FW.; Cole, SA. Assessment of depression and grief reactions in the medically ill. In: Stoudemire, A.; Fogel, BS.; Greenberg, DB., editors. Psychiatric care of the medical patient. 2. New York: Oxford University Press; 2000. p. 149-64.

45. King DA, Heisel MJ, Lyness JM. Assessment and psychological treatment of depression in older adults with terminal or life threatening illness. Clin Psychol Sci Pract. 2005; 12:339-53.

46. NHPCO's Facts and Figures - Hospice Care in America. National Hospice and Palliative Care Organization; 2013. [cited 2013]; Available from: http://www.nhpco.org/sites/default/files/public/ Statistics_Research/2013_Facts_Figures.pdf

47. Mercadante S, Arcuri E, Ferrera P, Villari P, Mangione S. Alternative treatments of breakthrough pain in patients receiving spinal analgesics for cancer pain. J Pain Symptom Manage. 2005; 30(5): 485-91. [PubMed: 16310622]

48. Carr DB, Goudas LC, Denman WT, Brookoff D, Staats PS, Brennen L, et al. Safety and efficacy of intranasal ketamine for the treatment of breakthrough pain in patients with chronic pain: a randomized, double-blind, placebo-controlled, crossover study. Pain. 2004; 108(1-2):17-27. [PubMed: 15109503] 
49. Kannan TR, Saxena A, Bhatnagar S, Barry A. Oral ketamine as an adjuvant to oral morphine for neuropathic pain in cancer patients. J Pain Symptom Manage. 2002; 23(1):60-5. [PubMed: 11779670]

50. Lauretti GR, Lima IC, Reis MP, Prado WA, Pereira NL. Oral ketamine and transdermal nitroglycerin as analgesic adjuvants to oral morphine therapy for cancer pain management. Anesthesiology. 1999; 90(6):1528-33. [PubMed: 10360847]

51. Mercadante S, Arcuri E, Tirelli W, Casuccio A. Analgesic effect of intravenous ketamine in cancer patients on morphine therapy: a randomized, controlled, double-blind, crossover, double-dose study. J Pain Symptom Manage. 2000; 20(4):246-52. [PubMed: 11027905]

52. Subramaniam K, Subramaniam B, Steinbrook RA. Ketamine as adjuvant analgesic to opioids: a quantitative and qualitative systematic review. Anesth Analg. 2004; 99(2):482-95. table of contents. [PubMed: 15271729]

53. Lossignol DA, Obiols-Portis M, Body JJ. Successful use of ketamine for intractable cancer pain. Support Care Cancer. 2005; 13(3):188-93. [PubMed: 15480820]

54. Fitzgibbon EJ, Hall P, Schroder C, Seely J, Viola R. Low dose ketamine as an analgesic adjuvant in difficult pain syndromes: a strategy for conversion from parenteral to oral ketamine. J Pain Symptom Manage. 2002; 23(2):165-70. [PubMed: 11844639]

55. Fine PG. Low-dose ketamine in the management of opioid nonresponsive terminal cancer pain. $\mathbf{J}$ Pain Symptom Manage. 1999; 17(4):296-300. [PubMed: 10203883]

56. Clark JL, Kalan GE. Effective treatment of severe cancer pain of the head using low-dose ketamine in an opioid-tolerant patient. J Pain Symptom Manage. 1995; 10(4):310-4. [PubMed: 7541437]

57. Irwin SA, Iglewicz A. Oral ketamine for the rapid treatment of depression and anxiety in patients receiving hospice care. J Palliat Med. 2010; 13(7):903-8. [PubMed: 20636166]

58. Irwin SA, Iglewicz A, Nelesen RA, Lo JY, Carr CH, Romero SD, et al. Daily oral ketamine for the treatment of depression and anxiety in patients receiving hospice care: a 28-day open-label proofof-concept trial. J Palliat Med. 2013; 16(8):958-65. [PubMed: 23805864]

59. Stefanczyk-Sapieha L, Oneschuk D, Demas M. Intravenous ketamine "burst" for refractory depression in a patient with advanced cancer. J Palliat Med. 2008; 11(9):1268-71. [PubMed: 19021495]

60. Guy, W. ECDEU Assessment Manual for Psychopharmacology — Revised. Rockville, MD: U.S. Department of Health, Education, and Welfare, Public Health Service, Alcohol, Drug Abuse, and Mental Health Administration, NIMH Psychopharmacology Research Branch, Division of Extramural Research Programs; 1976.

61. Irwin SA, Pirrello RD, Hirst JM, Buckholz GT, Ferris FD. Clarifying delirium management: practical, evidenced-based, expert recommendations for clinical practice. J Palliat Med. 2013; 16(4):423-35. [PubMed: 23480299]

62. Goodman, LS.; Gilman, A.; Brunton, LL.; Lazo, JS.; Parker, KL. Goodman \& Gilman's the pharmacological basis of therapeutics. 11. New York: McGraw-Hill; 2006.

63. Kurul S, Saip P, Aydin T. Totally implantable venous-access ports: local problems and extravasation injury. Lancet Oncol. 2002; 3(11):684-92. [PubMed: 12424071]

64. Monreal M, Davant E. Thrombotic complications of central venous catheters in cancer patients. Acta Haematol. 2001; 106(1-2):69-72. [PubMed: 11549779]

65. Sasson M, Shvartzman P. Hypodermoclysis: an alternative infusion technique. Am Fam Physician. 2001; 64(9):1575-8. [PubMed: 11730312] 


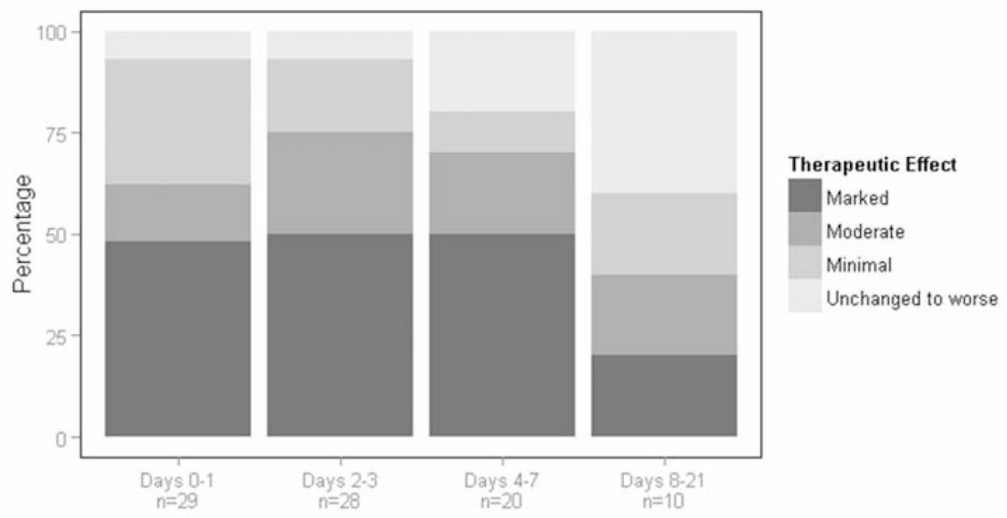

Figure $1 \mathrm{~A}$

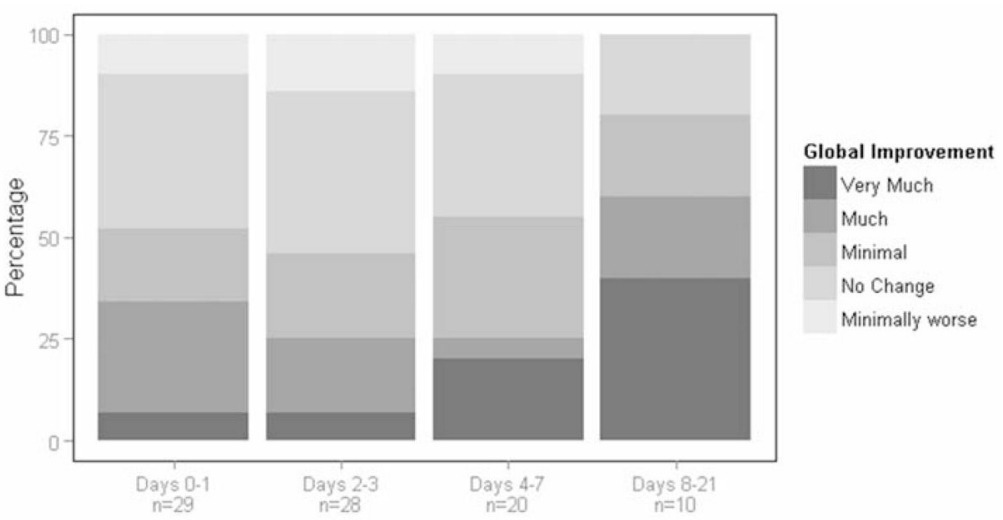

Figure 1B

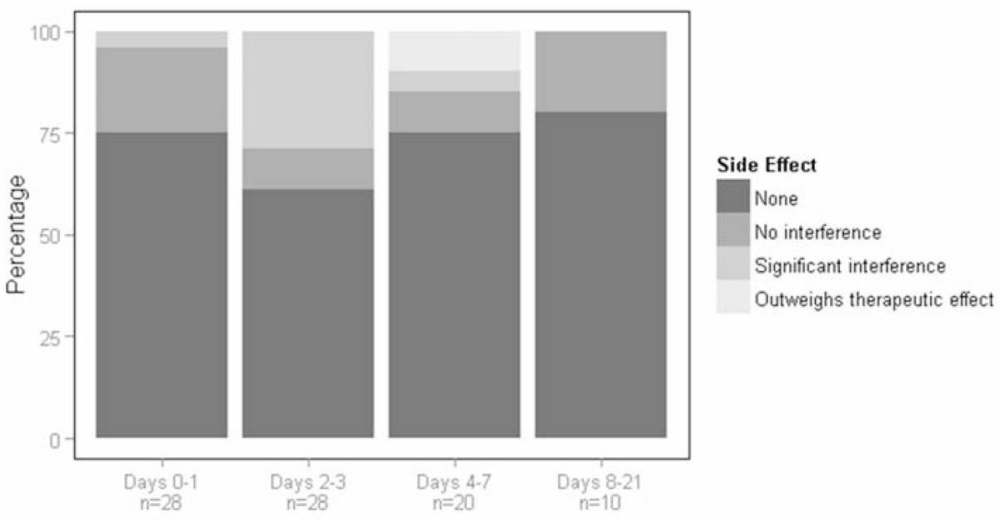

Figure $1 \mathrm{C}$

Figure 1.

Figures 1A-C: Graphic summaries of the data. The four bars represent the four time periods post ketamine dosing and each bar goes from zero to 100 percent. Each bar designates 
cumulative percentages going from the best to the worst category. Figure $1 \mathrm{~A}$ is a graphic summary of the therapeutic index scale of the CGI and represents data from the best category of "marked improvement" to the worst category of "unchanged to worse". Figure 1B is a graphic summary of the global improvement scale of the CGI and represents data from the best category of "very much improved" to "very much worse". Since no subjects were rated as "very much worse", the worst category reflected in the figure is "minimally worse". Figure 1C is a graphic summary of the side effects scale of the CGI and represents data from the best category of "none" to the worst category of "outweighs therapeutic effect". 


\section{Table 1}

\begin{tabular}{|c|c|c|}
\hline \multirow{7}{*}{ 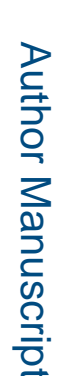 } & \multicolumn{2}{|l|}{ Demographics } \\
\hline & Gender & Number of Subjects \\
\hline & Male & $11(35.5 \%)$ \\
\hline & Female & $20(64.5 \%)$ \\
\hline & $\underline{\text { Age }}$ & $\underline{\text { Years }}$ \\
\hline & Average & 68 \\
\hline & Median & 66 \\
\hline & Range & $44-89$ \\
\hline & $\underline{\text { Marital Status }}$ & $\underline{\text { Number of Subjects }}$ \\
\hline & Single & $5(16 \%)$ \\
\hline & Married & $11(35 \%)$ \\
\hline & Widowed & $5(16 \%)$ \\
\hline & Divorced & $5(16 \%)$ \\
\hline & Unknown & $5(16 \%)$ \\
\hline & Medical Diagnosis & Number of Subjects \\
\hline & Neoplasm & $24(77 \%)$ \\
\hline & Coronary artery disease & $1(3 \%)$ \\
\hline & Liver failure & $1(3 \%)$ \\
\hline & Failure to Thrive & $2(6 \%)$ \\
\hline & Debility & $3(10 \%)$ \\
\hline & $\underline{\text { Length of Stay on Hospice }}$ & $\underline{\text { Number of Days }}$ \\
\hline & Average & 149 \\
\hline & Median & 89 \\
\hline
\end{tabular}

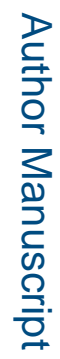

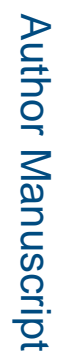

Psychosomatics. Author manuscript; available in PMC 2016 July 01. 


\section{Table 2}

\section{Ketamine Dosing}

\begin{tabular}{|l|l|}
\hline Dosing Route & Number of Subjects \\
Oral & $29(93.5 \%)$ \\
Subcutaneous & $1(3.2 \%)$ \\
Oral followed by Subcutaneous & $1(3.2 \%)$ \\
Dosing & Number of Subjects \\
TID dosing & $4(12.9 \%)$ \\
Single dose & $22(71 \%)$ \\
Repeat single dose & $5(16.1 \%)$ \\
\hline
\end{tabular}

Single Dose of Ketamine $=0.5 \mathrm{mg} / \mathrm{kg}$ 


\section{Table 3}

Clinical Global Improvement Scale Results

\begin{tabular}{|c|c|c|c|c|}
\hline \multicolumn{5}{|c|}{ A. Therapeutic Effect Scale of the CGI } \\
\hline Classification & Days 0 - 1 & Days 2 -3 & Days 4-7 & Days 8-21 \\
\hline Positive outcome & 27 & 26 & 16 & 6 \\
\hline Negative outcome & 2 & 2 & 4 & 4 \\
\hline P - value & $<0.001$ & $<0.001$ & $<0.05$ & $>0.05$ \\
\hline
\end{tabular}

\begin{tabular}{|c|c|c|c|c|}
\hline \multicolumn{5}{|c|}{ B. Global Improvement Scale of the CGI } \\
\hline Classification & Days 0 - 1 & Days 2 - 3 & Days 4-7 & Days 8-21 \\
\hline Positive outcome & 15 & 13 & 11 & 8 \\
\hline Negative outcome & 3 & 4 & 2 & 0 \\
\hline P - value & $<0.05$ & $<0.05$ & $<0.05$ & $<0.05$ \\
\hline
\end{tabular}

C. Side Effects Scale of the CGI

\begin{tabular}{|c|c|c|c|c|}
\hline \multicolumn{7}{|c|}{ C. Side Effects Scale of the CGI } \\
\hline Classification & Days 0 - 1 & Days 2 - 3 & Days 4- 7 & Days 8 - 21 \\
\hline Positive outcome & 27 & 20 & 17 & 10 \\
\hline Negative outcome & 1 & 8 & 3 & 0 \\
\hline P - value & $<0.001$ & $<0.05$ & $<0.05$ & $<0.001$ \\
\hline
\end{tabular}




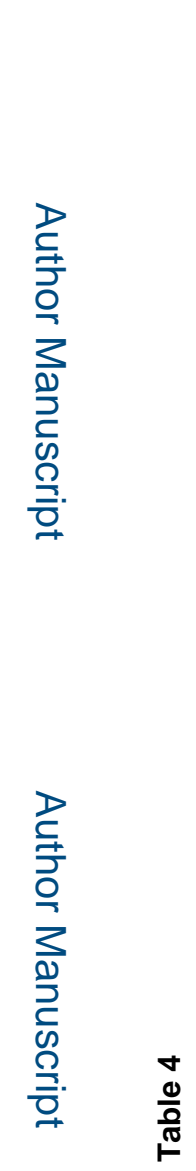

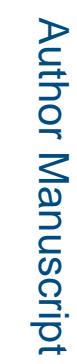

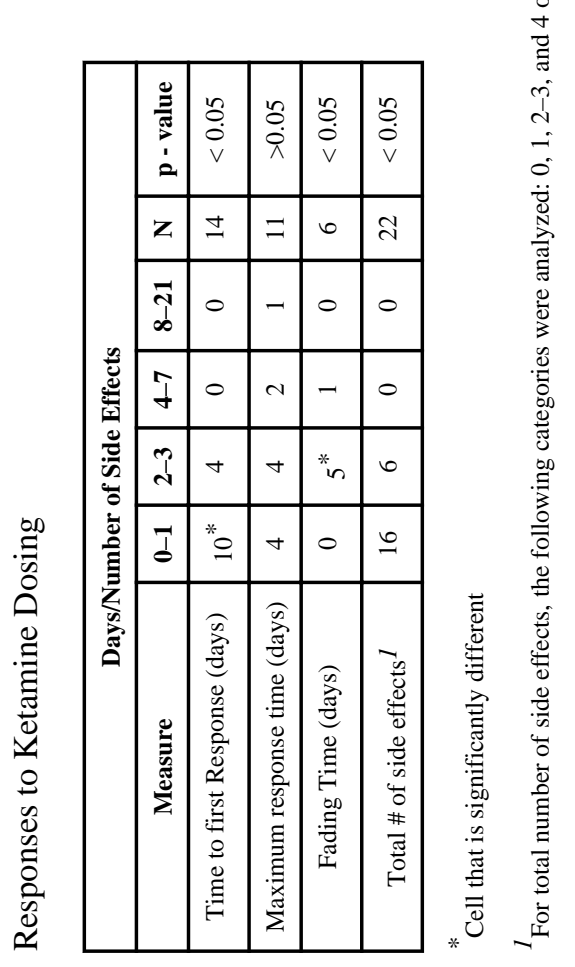

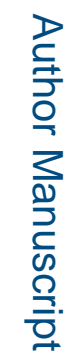

Psychosomatics. Author manuscript; available in PMC 2016 July 01. 